\title{
Leptin directly regulates bone cell function in vitro and reduces bone fragility in vivo
}

\author{
J Cornish, K E Callon, U Bava, C Lin, D Naot, B L Hill, A B Grey, \\ N Broom ${ }^{1}$, D E Myers ${ }^{2}$, G C Nicholson ${ }^{2}$ and I R Reid \\ Department of Medicine, University of Auckland, Private Bag 92019, Auckland, New Zealand \\ ${ }^{1}$ School of Engineering, University of Auckland, Auckland, New Zealand \\ ${ }^{2}$ Department of Clinical and Biomedical Sciences, Barwon Health, University of Melbourne, Australia \\ (Requests for offprints should be addressed to J Cornish; Email: j.cornish@auckland.ac.nz)
}

\begin{abstract}
Fat mass is an important determinant of bone density, but the mechanism of this relationship is uncertain. Leptin, as a circulating peptide of adipocyte origin, is a potential contributor to this relationship. Recently it was shown that intracerebroventricular administration of leptin is associated with bone loss, suggesting that obesity should be associated with low bone mass, the opposite of what is actually found. Since leptin originates in the periphery, an examination of its direct effects on bone is necessary to address this major discrepancy.

Leptin $\left(>10^{-11} \mathrm{M}\right)$ increased proliferation of isolated fetal rat osteoblasts comparably with IGF-I, and these cells expressed the signalling form of the leptin receptor. In mouse bone marrow cultures, leptin $\left(\geq 10^{-11} \mathrm{M}\right)$ inhibited osteoclastogenesis, but it had no effect on bone resorption in two assays of mature osteoclasts. Systemic administration of leptin to adult male mice (20 injections
\end{abstract}

of $43 \mu \mathrm{g}$ /day over 4 weeks) reduced bone fragility (increased work to fracture by $27 \%$ and displacement to fracture by $21 \%, P<0 \cdot 001)$. Changes in tibial histomorphometry were not statistically significant apart from an increase in growth plate thickness in animals receiving leptin. Leptin stimulated proliferation of isolated chondrocytes, and these cells also expressed the signalling form of the leptin receptor.

It is concluded that the direct bone effects of leptin tend to reduce bone fragility and could contribute to the high bone mass and low fracture rates of obesity. When administered systemically, the direct actions of leptin outweigh its centrally mediated effects on bone, the latter possibly being mediated by leptin's regulation of insulin sensitivity.

Journal of Endocrinology (2002) 175, 405-415

\section{Introduction}

Low body weight has long been recognised as one of the common clinical associations of osteoporosis (Felson et al. 1993). Epidemiological studies have demonstrated that low body weight is a risk factor for fractures of both the proximal femur and the vertebrae (Gardsell et al. 1989, Hassager \& Christiansen 1989, Greenspan et al. 1994). The advent of bone densitometry permitted the demonstration that bone density itself is also closely related to body weight (Mazess et al. 1987). Dual-energy X-ray absorptiometry permits body weight to be divided into its fat and lean components. Using this technique, it has become clear that fat mass is a major correlate of bone density (Reid et al. 1992a,b), of the rate of postmenopausal bone loss (Reid et al. 1994a), and of fracture incidence (Schott et al. 1998).

The biological basis for the relationship between fat mass and bone density remains uncertain. It has been attributed to the biomechanical effect of load bearing on the skeleton. While this may contribute, it is not a complete explanation, since the correlations between fat mass and bone density in non-weight-bearing parts of the skeleton are comparable with those found axially (Reid et al. 1992a). Furthermore, in some studies the impact of fat mass on bone density has been found to be greater than that of lean mass, whereas if it was simply a load-bearing phenomenon the two would be expected to contribute equally (Compston et al. 1992, Reid et al. 1992a, 1994b, Khosla et al. 1996). A second explanation is that adipocytes are a major site of oestrogen production in postmenopausal women. Again, this is unlikely to be the whole explanation (van Beresteijn et al. 1992) and it does not explain the close relationship between fat mass and bone density in premenopausal women despite the insignificance of the adipocyte as a source of oestrogen in this age group (Reid et al. 1992b). A third possibility is that obesity influences bone density by way of its effects on circulating 
concentrations of bone-active hormones. Fat mass is a major determinant of circulating insulin concentrations and there is clear evidence that insulin acts both directly and indirectly on the skeleton (Reid et al. 1993, Cornish et al. 1996). Amylin, a hormone co-secreted with insulin from the beta cells of the pancreatic islets, also directly stimulates osteoblast activity and inhibits osteoclastic bone resorption (Cornish \& Reid 1999). There may be other hormones co-secreted from the beta cell or directly from the adipocyte that are also involved.

The identification of leptin as a major hormonal product of the adipocyte has raised the possibility that this peptide may contribute to the fat mass-bone density relationship. This would be possible if this hormone acted on bone. To date, it has been demonstrated that circulating leptin concentrations are related to bone mass (Goulding \& Taylor 1998, Pasco et al. 2001, Yamauchi et al. 2001, Blain et al. 2002), and that leptin levels are lower in women with vertebral fractures (Yamauchi et al. 2001), although association does not establish causality. Leptin has been shown to promote osteoblastic differentiation (Thomas et al. 1999) in a human osteoblast cell line but this has been contradicted by the recent work of Ducy et al. (2000), who concluded that there was no direct action of leptin on skeletal cells. In contrast, they demonstrated profound bone loss when leptin was administered into the cerebral ventricles of either wild-type or leptin-deficient mice. These experiments demonstrated that bone density was centrally regulated but left a major unresolved paradox, since they suggested that high leptin states such as obesity would be associated with low bone density, whereas the opposite is the case.

While the hypothalamus is an important site of leptin action, leptin originates outside the central nervous system, in the adipocyte. Therefore, to determine its effects on the skeleton of the intact animal, it is necessary to study the effects of its systemic administration - if it does have direct effects on bone, these will modify those arising from its central actions. The present paper addresses these questions by assessing the effects of leptin on skeletal cells in vitro, as well as assessing its integrated action following systemic administration in vivo.

\section{Materials and Methods}

\section{Osteoblast-like cell culture}

Osteoblasts were isolated from 20-day-old fetal rat calvariae as previously described (Cornish et al. 1999). Briefly, calvariae were excised and the frontal and parietal bones, free of suture and periosteal tissue, were collected. Usually, two litters were used for each osteoblast preparation. The calvariae were sequentially digested using collagenase and the cells from digests three and four were collected, pooled and washed. Cells were grown to confluence and then subcultured into $24-$ well plates. This preparation produces cells with a pre-osteoblast phenotype, evidenced by alkaline phosphatase expression but low basal expression of osteocalcin (Groot et al. 1985, Herrmann-Erlee \& van der Meer 1986). Cells were growth arrested in minimum essential medium (MEM) (Gibco BRL, Life Technologies, Auckland, NZ)/0.1\% BSA for $24 \mathrm{~h}$. Fresh medium and experimental compounds were added for a further $24 \mathrm{~h}$. Cells were pulsed with $\left[{ }^{3} \mathrm{H}\right]$ thymidine $2 \mathrm{~h}$ before the end of the experimental incubation. The experiment was terminated and both cell counts and thymidine incorporation were assessed. There were six wells in each group and each experiment was repeated three or four times. For the long-term cultures (10 and 21 days) the cells were grown initially as above. At the point of confluency, medium was supplemented with $50 \mathrm{mg} / \mathrm{ml}$ ascorbic-2-phosphate and $10 \mathrm{mM}$ $\beta$-glycerol phosphate to promote differentiation.

\section{Identification of leptin receptors}

Leptin receptors were identified by RT-PCR using osteoblast-like cells, prepared as above. Total cellular RNA was purified from cells and tissues by a modified method of single-step guanidinium thiocyanate-phenolchloroform RNA extraction (Chomczynski \& Sacchi 1987, Grey et al. 2001). RNA concentration and purity were determined by measuring the optical density using a Gene QuantTM spectrophotometer (Pharmacia, Little Chalfont, Bucks, UK) and the quality was determined by electrophoresis on a 1\% agarose gel. RNA was treated with DNase and RT-PCR amplifications were carried out following the previously published protocol (Grey et al. 2001). PCR was performed in an automatic DNA thermal cycler (Mastercycler Personal; Eppendorf, Hamburg, Germany). After an initial denaturation step of $2 \mathrm{~min}$ at $94{ }^{\circ} \mathrm{C}$, cycles of denaturing at $94{ }^{\circ} \mathrm{C}$ for $30 \mathrm{~s}$, annealing at $60{ }^{\circ} \mathrm{C}$ for $30 \mathrm{~s}$, and extension at $72{ }^{\circ} \mathrm{C}$ for $1 \mathrm{~min}$ were performed. PCR reaction products were visualised on a $1 \%$ TBE agarose gel. The primers used to amplify the leptin receptor (long form) from rat and human RNA were 5'GGTCCTCTTCTTTTGGAGCCTG and 5'GC TGGGAATGGGCACGATAC. For amplification of rat glyceraldehyde 3-phosphate dehydrogenase (GAPDH), the forward primer $5^{\prime}$ CATCATCTCCGCCCCTTCCG and the reverse primer 5'CCTGCTTCACCACCT TCTTG were used, while for the human GAPDH the forward primer 5'CATCATCTCTGCCCCCTCTG was used with the same reverse primer as for the rat GAPDH. Twenty-five amplification cycles were performed for the GAPDH, and 35 cycles for the leptin receptor. PCR products were purified from agarose gels using QIAquick gel extraction kit (Qiagen, Valencia, CA, USA), and their sequences were determined on an ABI 377 XL DNA Sequencer (PE Biosystems, Foster City, CA, USA). 


\section{Bone marrow culture}

Bone marrow was obtained from long bones of normal Swiss male mice aged 4-6 weeks. Approximately six animals were used per preparation. Mice were killed by cervical dislocation while under halothane anaesthesia. Femurs and tibiae were aseptically removed and dissected free of adhering tissues. The epiphyses were cut off with a scalpel blade and the marrow cavity was flushed with alpha minimum essential medium ( $\alpha$ MEM) using a syringe with a 23-gauge needle. The marrow cells were collected in a $50 \mathrm{ml}$ centrifuge tube, centrifuged at $232 \boldsymbol{g}$ for $2 \mathrm{~min}$ and washed with $10 \%$ fetal bovine serum (FBS) (Gibco, Grand Island, NY, USA)/ $\alpha$ MEM. Marrow cells were then cultured for $2 \mathrm{~h}$ in $90 \mathrm{~mm}$ Petri dishes. After $2 \mathrm{~h}$, nonadherent cells were collected, centrifuged at $232 \mathrm{~g}$ for 2 min, washed with $15 \%$ FBS/ $\alpha$ MEM and seeded at $10^{6}$ cells $/ \mathrm{ml}$ in 48-well plates (Costar, Cambridge, MA, USA) ( $0.5 \mathrm{ml} /$ well). 1,25-Dihydroxyvitamin $\mathrm{D}_{3}\left(1,25(\mathrm{OH})_{2} \mathrm{D}\right)$ $\left(10^{-8} \mathrm{M}\right)$ was added (day 0$)$ to all wells except to negative controls, which remained in the absence of $1,25(\mathrm{OH})_{2} \mathrm{D}$ throughout the experiment. Forty-eight hours later (day 2), cultures were fed $0.5 \mathrm{ml}$ fresh medium with $1,25(\mathrm{OH})_{2} \mathrm{D}$ to make a total of $1 \mathrm{ml} /$ well. After a further $48 \mathrm{~h}$ (day 4), cultures were fed by replacing $0.5 \mathrm{ml}$ old medium with fresh medium with $1,25(\mathrm{OH})_{2} \mathrm{D}$. Test substances were added to test groups and vehicle added to control groups at $0,2,4$ days, depending on the particular protocol. All cultures were maintained at $37^{\circ} \mathrm{C}$ in a humidified atmosphere of $5 \% \mathrm{CO}_{2}$ in air. After culture for 7 days, cells adherent to the well surface were fixed with citrate-acetone-formaldehyde $(25: 65: 8 \mathrm{v} / \mathrm{v})$ for $30 \mathrm{~s}$. Culture plates were then stained for tartrate-resistant acid phosphatase (TRAP) using Sigma Kit \#387-A (Sigma Diagnostics, St Louis, MO, USA). TRAP-positive multinucleated cells (containing three or more nuclei) were counted in all wells. Each experiment had three wells in which cells were grown on bone slices and checked for resorptive pits, indicating that the TRAP-positive multinucleated cells in these cultures were capable of resorbing bone. There were at least eight wells for each group and each experiment was repeated three or four times.

\section{Mature isolated osteoclast culture}

Rat osteoclasts were isolated from a litter of 1-day-old neonatal rats. The rats were killed by decapitation, and the long bones aseptically removed. The bones were dissected free of adherent soft tissues. Epiphyses were removed and the remaining diaphyses split longitudinally and then placed in a tissue homogeniser containing $2 \mathrm{ml}$ acidified aMEM $(72 \mu \mathrm{l}$ concentrated $\mathrm{HCl}$ per $80 \mathrm{ml}$ medium) with $10 \%$ FBS and antibiotics. Bones were homogenised gently and the cell suspension collected in a $15 \mathrm{ml}$ conical tube. The remaining bone tissue was placed in a small Petri dish with $1 \mathrm{ml}$ medium and chopped quickly with a scalpel blade. The resulting cell suspension was collected and added to the same conical tube. The bone tissue was homogenised again in $1 \mathrm{ml}$ medium and the suspension was once again collected. This osteoclast-rich suspension was placed onto bovine bone slices, approximately $9 \mathrm{~mm}^{2}$, in 96 -well plates and incubated at $37^{\circ} \mathrm{C}$ in a humidified atmosphere of $5 \% \mathrm{CO}_{2}$ in air for $35 \mathrm{~min}$ to allow the mature osteoclasts to settle. The bone slices were washed several times in PBS to remove contaminating nonosteoclastic cells followed by a rinse in medium. The bone slices were then placed in six-well plates (four slices per well) containing $6 \mathrm{ml}$ medium and incubated with test substances or vehicle for $20 \mathrm{~h}$. The identity of cells produced in this way as mature osteoclasts is attested to by their ability to resorb bone, by the presence of calcitonin receptors, by positive TRAP staining and by their being multinucleated.

After incubation the bone slices were fixed with 2.5\% glutaraldehyde/PBS and stained for TRAP using Sigma kit \#387-A. The number of TRAP-positive multinucleated (containing more than three nuclei) cells on each bone slice was quantified and the cells removed by gentle scrubbing and then stained for $30 \mathrm{~s}$ with toluidine blue. After numerous washes in water the bone slices were dried and then assessed for the 'pits' excavated by the osteoclasts. This was achieved using reflected light microscopy and metallurgic lenses. The results were expressed as a ratio of the number of pits:number of osteoclasts per bone slice. There were 6-12 bone slices in each group and each experiment was repeated two or three times.

\section{Bone organ culture}

Bone resorption studies were carried out in neonatal mouse calvariae as described previously (Reid et al. 1990). Mice were injected s.c. with $5 \mu \mathrm{Ci}{ }^{45} \mathrm{Ca}$ at 2 days of age, and hemi-calvariae were dissected out 4 days later. Hemi-calvariae were pre-incubated for $24 \mathrm{~h}$ in medium 199 with $0 \cdot 1 \%$ BSA, then changed to fresh medium containing test substances or vehicle. Incubation was continued for a further $48 \mathrm{~h}$. To assess DNA synthesis, $\left[{ }^{3} \mathrm{H}\right]$ thymidine $(0.6 \mu \mathrm{Ci} / \mathrm{ml})$ was added in the last $4 \mathrm{~h}$ of the incubation as described previously (Lowe et al. 1991). The experiment was terminated and both calcium release and thymidine incorporation were assessed. There were five to seven hemi-calvariae in each group and each experiment was repeated three or four times.

\section{Chondrocyte cell culture}

Chondrocytes were isolated by removing cartilage (fulldepth slices) from the tibial and femoral surfaces of adult dogs under aseptic conditions. Slices were placed in Dulbecco's Modified Eagle's medium (DMEM) containing 5\% FBS (v/v) and antibiotics (penicillin $50 \mathrm{U} / 1$, 
streptomycin $50 \mu \mathrm{g} / \mathrm{l}$ and neomycin $100 \mu \mathrm{g} / \mathrm{l}$ ) and chopped finely with a scalpel blade. Tissue was removed and incubated at $37{ }^{\circ} \mathrm{C}$ with pronase $(0.8 \% \mathrm{w} / \mathrm{v}$ for $90 \mathrm{~min})$ followed by collagenase $(0 \cdot 1 \% \mathrm{w} / \mathrm{v}$ for $18 \mathrm{~h})$ to complete the digestion. The cells were isolated from the digest by centrifugation (10 $\mathrm{min}$ at $272 \mathrm{~g}$ ), resuspended in DMEM/5\%FBS, passed through a nylon mesh screen of $90 \mu \mathrm{m}$ pore size to remove any undigested fragments, and recentrifuged. The cells were washed and resuspended twice in the same medium and seeded into a $75 \mathrm{~cm}^{2}$ flask containing DMEM $/ 10 \% \mathrm{FBS} / 50 \mu \mathrm{g} / \mathrm{ml}$ ascorbic acid. The cells were incubated under $5 \% \mathrm{CO}_{2} / 95 \%$ air at $37^{\circ} \mathrm{C}$. Confluence was reached by 7 days, at which time the cells were subcultured. After trypsinisation using trypsin-EDTA $(0 \cdot 05 \% / 0.53 \mathrm{mM})$, the cells were rinsed in $\mathrm{DMEM} / 5 \% \mathrm{FBS} / 50 \mu \mathrm{g} / \mathrm{ml}$ ascorbic acid and resuspended in fresh medium, then seeded into $24-$ well plates $\left(5 \times 10^{4}\right.$ cells $/ \mathrm{ml}, 0.5 \mathrm{ml} /$ well). Measurement of cell numbers and thymidine incorporation were performed in growtharrested cell populations as for the osteoblast-like cell cultures. For the human chondrocyte cultures, articular cartilage was obtained from knee joints of 50- to 70-yearold patients undergoing joint replacement. The cartilage slices excised were from non-diseased areas and tissue appeared normal. The chondrocytes were isolated by pronase/collagenase digestion as above.

\section{Systemic study}

Experimental design Two groups of 20 sexually mature male Swiss mice aged between 40 and 50 days and weighing 25-36 g, were given daily s.c. injections ( $43 \mu \mathrm{g}$ recombinant murine leptin in $50 \mu$ l water, or water alone) in the loose skin at the nape of the neck for 5 days/week over 4 consecutive weeks. This dose was chosen because the same molar doses $(93 \mathrm{nmol} / \mathrm{kg})$ of amylin and adrenomedullin in this model produce substantial effects on bone turnover and bone area (Cornish et al. 1998, 2001). These peptides have similar effects on osteoblast proliferation to leptin (vide infra). Animals were housed in a room maintained at $20^{\circ} \mathrm{C}$ on $12 \mathrm{~h}$ light: $12 \mathrm{~h}$ darkness cycles. They were fed diet 86 rodent pellets (NRM NZ Ltd, Takanini, New Zealand) freely throughout the experiment. Each animal's weight was recorded at the beginning and end of the experiment. The study had the approval of the local institutional review board.

Histomorphometry Indices of bone formation and resorption, and bone volume were assessed in the proximal tibiae. One tibia from each animal was used for histomorphometric analyses. The tibiae were dissected free of adherent tissue and bone lengths were recorded by measuring the distance between the proximal and the distal epiphysis using an electronic micrometer (Digimatic Calipers, Mitutoyo, Japan). Tibiae were then processed as previously described (Cornish et al. 2000). Briefly, bones were fixed in 10\% phosphate-buffered formalin for $24 \mathrm{~h}$ and then dehydrated in a graded series of ethanol solutions and embedded, undecalcified, in methylmethacrylate resin. Tibiae were sectioned longitudinally through the frontal plane. Sections ( $4 \mu \mathrm{m}$ thick) were cut using a rotary microtome and a tungsten carbide knife, then mounted on gelatin-coated slides and air-dried. They were stained with Goldner's tri-chrome and examined using an Olympus BX 50 microscope (Olympus, Tokyo, Japan), which was attached to an Osteomeasure Image Analyzer (Osteometric, Atlanta, GA, USA).

Tibial histomorphometric analyses were made from three adjacent sections one-third of the way through the anterior/posterior depth of the proximal tibiae. All trabecular bone tissue in the secondary spongiosa was quantified for bone volume in each section using a $\times 10$ objective, and parameters were derived using the formulae of Parfitt et al. (1983). Parameters of bone formation and resorption were measured using a $\times 20$ objective in all trabecular bone tissue in the secondary spongiosa in the second of the three adjacent sections. The surfaces measured were those immediately adjacent to unmineralised matrix, those adjacent to osteoblasts, and those adjacent to osteoclasts (osteoid, osteoblast and osteoclast perimeters respectively). Perimeters and cell numbers were expressed per section. Cortical width was measured on both sides of the tibial shaft, $2.5 \mathrm{~mm}$ below the epiphyseal growth plate. Epiphyseal growth plate thickness was measured at three sites evenly spaced along its length. All measurements were made by one operator (J C) who was blinded to the treatment group of each bone. The precisions of these histomorphometric measurements in our laboratory (expressed as coefficients of variation of paired measurements) are as follows: mineralised bone area $1.3 \%$, osteoid perimeter $6.9 \%$, osteoblast perimeter $6 \cdot 8 \%$, osteoblast number $1 \cdot 7 \%$, osteoclast perimeter $7 \cdot 9 \%$, osteoclast number $<1 \cdot 0 \%$, width measurements $1 \cdot 7 \%$.

Mechanical assessment of the tibia The remaining tibia from each animal, stored frozen, was thawed and its mechanical properties assessed by means of a three-point bending test. Each tibia was dissected free of soft tissue and tested on a universal testing machine (Model 1186; Instron, Canton, MA, USA) equipped with a $5000 \mathrm{~N}$ load transducer. Samples were tested at room temperature with a support span of $10 \mathrm{~mm}$. Appropriately shaped beam end supports were used to minimise twisting of the bone about its long axis. Load was applied at a constant deformation rate of $2 \mathrm{~mm} / \mathrm{min}$. Load-deformation curves were recorded and displacement values (a measurement of how much the bone deflects in bending up to point of fracture) were obtained directly from the curve and expressed in millimetres.

Fat mass estimations Fat mass estimations were made from measurements of the animals' body densities 
calculated from water displacement. Immediately after death the mice were submerged head-first to the base of the tail into a $250 \mathrm{ml}$ measuring cylinder containing $150 \mathrm{ml}$ water and the displacement volume recorded. The fraction of body weight that was fat mass was calculated using a modification of the Siri equation for use in rodents (Muscaritoli et al. 1993). The coefficient of variation for repeated measures of fat mass was $7 \%$.

\section{Statistical analysis}

Data are presented as means \pm S.E. Where parameters were measured more than once in each animal (e.g. cortical thickness), these values were averaged to produce a single value for each animal before further analysis. The significance of treatment effects was evaluated using Student's $t$-tests for unpaired data and a 5\% significance level was maintained.

\section{Results}

\section{Osteoblasts}

Leptin produced a dose-related increase in both thymidine incorporation and cell number in primary cultures of osteoblast-like cells at $24 \mathrm{~h}$ (Fig. 1a, 1b). Both effects were statistically significant at leptin concentrations of $10^{-10} \mathrm{M}$, although cell number were already showing an upward trend at $10^{-11} \mathrm{M}$. For purposes of comparison, the effects of maximally effective concentrations of a number of classic osteoblast mitogens are also shown in Fig. 1c. It can be seen that the effects of leptin are of comparable magnitude. Leptin mRNA was not detected using RT-PCR in these osteoblast cultures (data not shown).

\section{Leptin receptors}

In view of the activity of leptin on isolated osteoblasts, we determined whether these cells expressed the signalling form of the leptin receptor. Figure 2a shows results from a representative study using semi-quantitative RT-PCR. mRNA for the leptin receptor was detectable in these cells, although its level of expression was lower than in rat hypothalamic RNA that was used as a positive control. The expression of the leptin receptor was also studied in isolated osteoblasts that were cultured for 5 or 10 days, and in cells cultured for 21 days, which are more differentiated and are capable of forming bone nodules. As shown in Fig. $2 \mathrm{~b}$, the levels of expression of the leptin receptor were similar in all these RNA samples.

\section{Osteoclasts}

The effects of leptin on osteoclast development were assessed in mouse bone marrow cultures. The number (a)

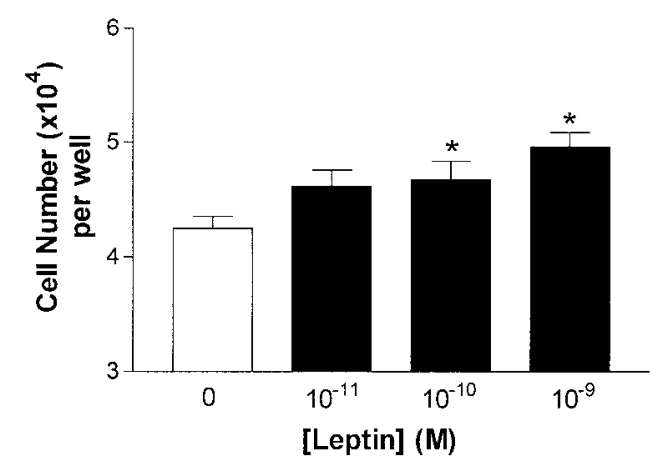

(b)

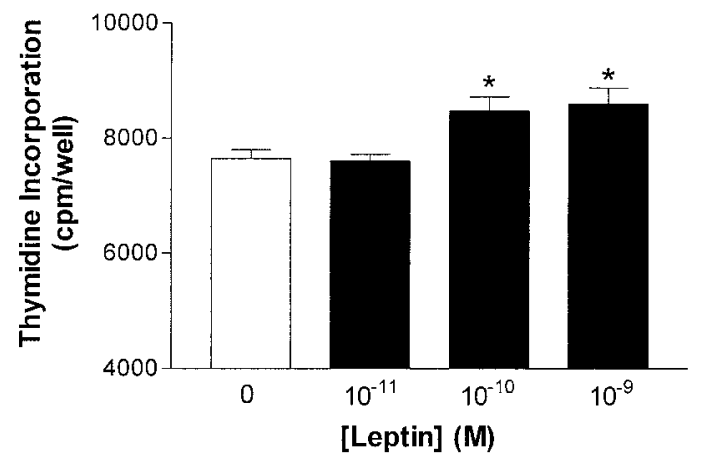

(c)

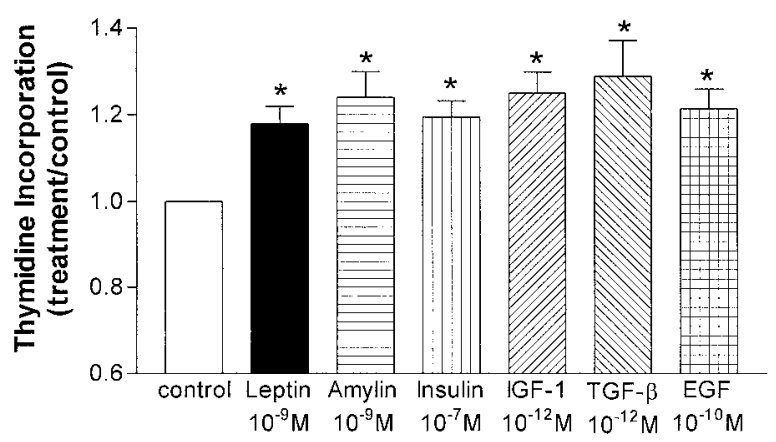

Figure 1 Effect of leptin on: (a) cell number, and (b) thymidine incorporation in primary cultures of fetal rat osteoblasts at $24 \mathrm{~h}$. In (c), the response to a maximal dose of leptin is compared with those to maximal concentrations of a number of other osteoblast growth factors (IGF-I, insulin-like growth factor; TGF- $\beta$, transforming growth factor- $\beta$; EGF, epidermal growth factor). Means \pm S.E.M. Data pooled from more than one experiment are shown as treatment/control ratios. *Significantly different from control; $P \leq 0.05$ in (a), $P \leq 0.01$ in (b, c).

of multinucleated, TRAP-positive cells was significantly decreased by leptin concentrations as low as $10^{-11} \mathrm{M}$ (Fig. 3a). These effects are comparable in magnitude with 
(a)

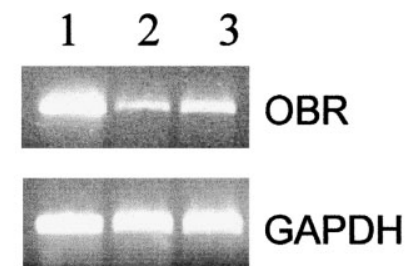

(b)

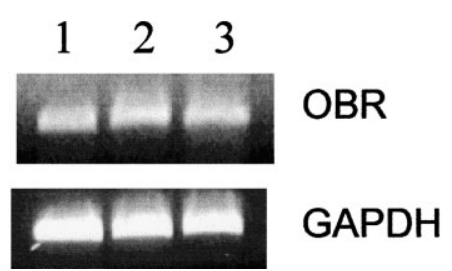

Figure 2 (a) Expression of the long (signalling) form of the leptin receptor assessed by RT-PCR. Lane 1, rat hypothalamus; lane 2, rat primary osteoblast culture; lane 3, human chondrocyte culture. (b) Expression of the leptin receptor in rat primary osteoblasts after 5 days (lane 1), 10 days (lane 2) and 21 days (lane 3 ) in culture. OBR, long form of leptin receptor.

those we have shown with weak anti-osteoclast factors such as amylin, but very much less than those observed with calcitonin (data not shown).

In contrast, leptin had no effect in two models of mature osteoclast activity. Pit formation on bovine bone by isolated mature rat osteoclasts was unaffected by leptin in concentrations as high as $10^{-8} \mathrm{M}$ (Fig. 3b). Similarly, calcium release from cultured neonatal mouse calvariae was unaffected by multiple additions of leptin in concentrations as high as $10^{-7} \mathrm{M}$. Findings were similar whether the effect of leptin was assessed on basal resorption or on resorption stimulated by parathyroid hormone (Fig. 3c).

\section{In vivo}

Normal adult male mice were treated systemically with leptin or vehicle over a 4 week period. Histomorphometry data from the proximal tibiae of these animals are given in Table 1 - the only significant difference between the groups was in growth plate thickness, which was greater in the animals treated with leptin. However, when bone mechanical properties were assessed by three-point bending, both the work to failure and the displacement to failure were significantly increased in the animals treated with leptin (Fig. 4).

Weight increased from $27 \cdot 5 \pm 0 \cdot 8$ to $33 \cdot 6 \pm 0.8 \mathrm{~g}$ in the course of the study in animals treated with vehicle,

Table 1 Effects of leptin treatment on bone histomorphometry. Data are means \pm S.E.M.

\begin{tabular}{|c|c|c|}
\hline & Control & Leptin \\
\hline \multicolumn{3}{|l|}{ Parameter } \\
\hline Osteoblast number & $600 \pm 50$ & $640 \pm 40$ \\
\hline Osteoid perimeter (mm) & $5 \cdot 0 \pm 0 \cdot 6$ & $6 \cdot 2 \pm 0 \cdot 7$ \\
\hline Osteoclast number & $8 \cdot 0 \pm 0 \cdot 8$ & $7 \cdot 3 \pm 0 \cdot 7$ \\
\hline Bone volume (\%) & $19 \cdot 0 \pm 1.3$ & $18 \cdot 0 \pm 1 \cdot 4$ \\
\hline Cortical thickness (mm) & $0 \cdot 189 \pm 0 \cdot 005$ & $0 \cdot 197 \pm 0 \cdot 008$ \\
\hline Growth plate thickness (mm) & $0 \cdot 083 \pm 0 \cdot 004$ & $0 \cdot 099 \pm 0.004^{*}$ \\
\hline Mid-tibial width $(\mathrm{mm})$ & $0 \cdot 30 \pm 0 \cdot 02$ & $0 \cdot 32 \pm 0 \cdot 02$ \\
\hline
\end{tabular}

*Significantly different from control, $P=0 \cdot 01$. and those receiving leptin showed comparable changes $(27 \cdot 2 \pm 1 \cdot 0$ to $32 \cdot 5 \pm 1 \cdot 0 \mathrm{~g})$. The per cent fat mass of the animals at the end of the experiment was lower in the leptin animals $(8.7 \pm 0.3 \%)$ than in the control group $(10 \cdot 2 \pm 0 \cdot 5 \%, P=0 \cdot 01)$. Tibial lengths were not different between the groups (control $18.6 \pm 0.1 \mathrm{~mm}$, leptin $18 \cdot 7 \pm 0 \cdot 0 \mathrm{~mm})$.

\section{Chondrocytes}

In view of the effects of leptin administration on growth plate thickness, its effect on proliferation of primary cultures of canine chondrocytes was also assessed. Leptin at $10^{-10} \mathrm{M}$ increased numbers of chondrocytes from $3.11 \pm 0.08 \times 10^{4}$ in control cultures to $3.36 \pm 0.06 \times$ $10^{4}(P<0 \cdot 05)$. Thymidine incorporation showed a similar response: control, $23704 \pm 288$ d.p.m./well; leptin, $25708 \pm 396$ d.p.m./well $(P=0 \cdot 002)$. Similar results were obtained from a preparation of ovine chondrocytes (data not shown). The expression of the leptin receptor was demonstrated in RNA from a primary human chondrocyte culture using RT-PCR (Fig. 2a, lane 3).

\section{Discussion}

The present studies assess the skeletal actions of leptin in a number of different models, and indicate that it has modest direct effects on bone cells leading to reduced bone fragility. Leptin promotes growth in cultures of both primary osteoblasts and chondrocytes. This anabolic effect is consistent with the data from Thomas et al. (1999) in a human marrow stromal cell line indicating that leptin promoted differentiation into an osteoblast phenotype and that it increased synthesis of bone matrix proteins such as type I collagen and osteocalcin. Similar findings have been reported by Gordeladze et al. (2002). The present findings are also consistent with the data from Steppan et al. (2000) who found that the in vivo administration of leptin to $\mathrm{ob} / \mathrm{ob}$ mice resulted in increases in both bone size and 
(a)

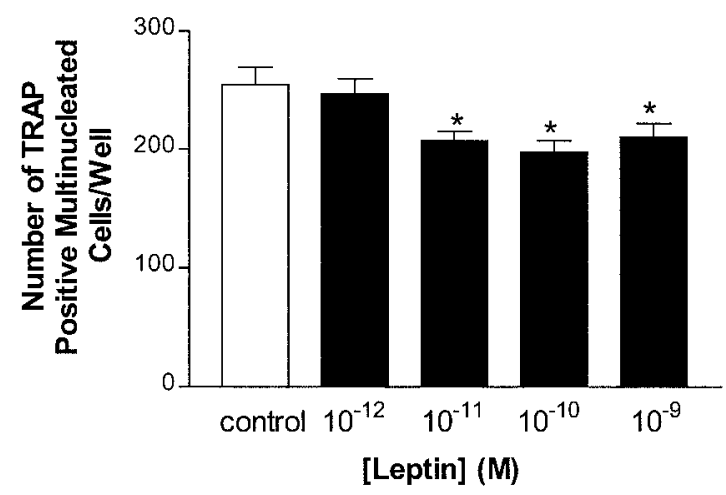

(b)

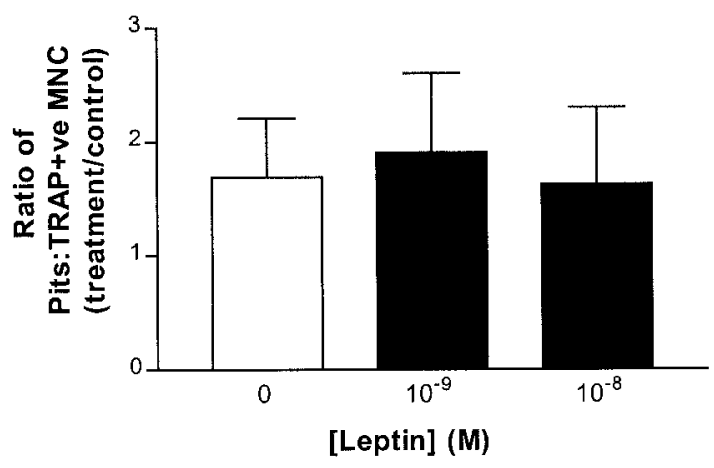

(c)

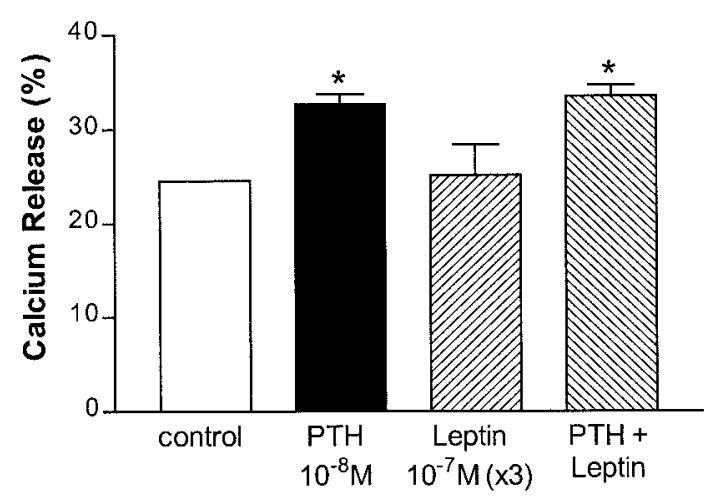

Figure 3 (a) Effect of leptin on osteoclast development in mouse bone marrow cultures. The number of multinucleated, TRAP-positive cells was significantly decreased by leptin.

*Significantly different from control, $P<0 \cdot 04$. (b) Effect of leptin on pit formation on bovine bone by isolated mature rat osteoclasts. No significant effects were detected. (c) Effect of leptin on basal calcium release and that stimulated by $10^{-8} \mathrm{M}$ parathyroid hormone (PTH) in cultured neonatal mouse calvariae. Leptin was added in a concentration of $10^{-7} \mathrm{M}$ three times during the $48 \mathrm{~h}$ incubation period. There were no significant effects of leptin on calcium release. ${ }^{*}$ Significantly different from control, $P<0 \cdot 008$. Means \pm S.E.M. (a)

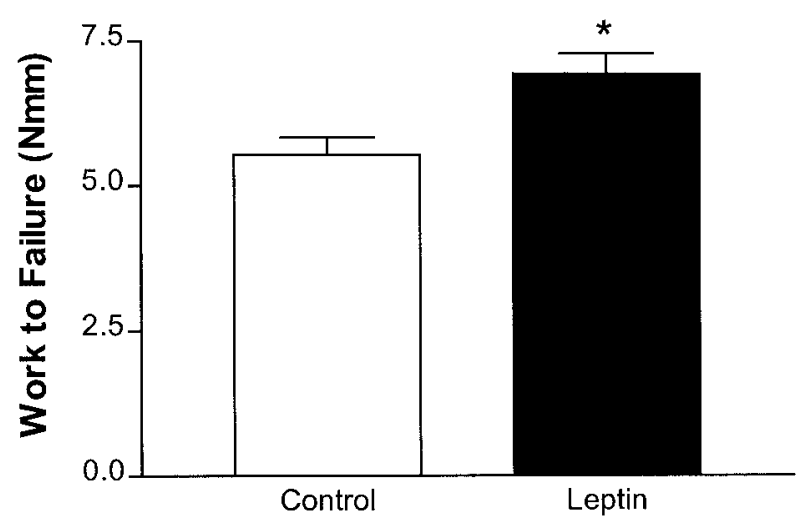

(b)

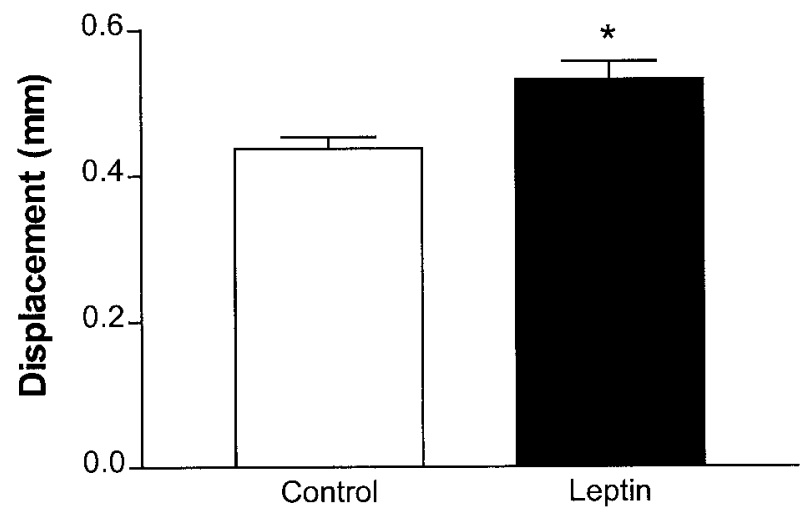

Figure 4 Effect of leptin on bone fragility in the tibia of normal adult mice treated with leptin at $43 \mu \mathrm{g} /$ day for 4 weeks, or vehicle. Means \pm S.E.M. The indices shown were determined from load-deformation curves during three-point bending. *Significantly different from control, $P<0 \cdot 001$.

bone mass. A similar in vivo study in ob/ob mice, published in abstract form only, indicates that leptin replacement increases osteoblast number more than 20-fold, with accompanying substantial increases in bone formation rates (Liu et al. 1997). Also in agreement with the present results, Iwaniec et al. (1998) have provided a preliminary report of dose-related increases in the number of mineralised bone nodules formed in vitro after 14 days of treatment of primary osteoblast cultures with leptin in concentrations between 1 and $100 \mathrm{ng} / \mathrm{ml}$. These results have been confirmed by Reseland et al. (2001). Together these studies provide a compelling body of evidence that leptin has direct anabolic effects on osteoblasts. This is supported by our demonstration of the signalling form of the leptin receptor in primary rat osteoblast cultures and human chondrocytes. This receptor has also been found in 
human osteoblasts (Steppan et al. 2000, Enjuanes et al. 2002), rat osteoblasts (Lee et al. 2001), porcine chondrocytes (Steppan et al. 2000), human mesenchymal stem cells undergoing osteogenic differentiation (Bassilana et al. 2000), and in osteoblastic and chondrocytic cell lines (Sufang et al. 2000, Lee et al. 2001), supporting the present evidence that leptin plays a role in skeletal physiology.

Leptin also acts on bone resorption, reducing osteoclast formation in mouse bone marrow cultures. This is consistent with the finding of an inverse relationship between serum leptin and bone resorption markers in human fetuses (Ogueh et al. 2000) and in postmenopausal women (Blain et al. 2002), and with the report from Holloway et al. (2002) of an inhibition of osteoclast generation in an assay using human peripheral blood mononuclear cells. Those studies suggested that the effect was mediated by leptin-induced changes in mononuclear cell production of receptor activator of NF-KB (RANK), and are complemented by the report of Burguera et al. (2001) that leptin increases osteoprotegerin levels and decreases RANK ligand levels in human marrow stromal cells. Indeed, leptin may have a wider role in the regulation of bone marrow cells, since there is also evidence that it stimulates haematopoiesis and immune cell generation (Pighetti et al. 1999). However, the present studies indicate that leptin does not act on mature osteoclasts, whether assessed in isolated cells or in an organ culture system in which there is very little osteoclast generation.

This is the first study to assess the effects of systemic leptin administration on bone histomorphometry and strength in wild-type animals. The upward trends in osteoblast indices and the downward trend in osteoclast number reflect the changes seen in the in vitro studies. They may be smaller in vivo because of osteoblastosteoclast coupling and the fact that leptin exerts opposite effects on formation and resorption. Burguera et al. (2001) also found no effects of leptin on forming and resorbing surfaces in ovarectomised rats, although they did find a reduction in trabecular bone loss. The significant reduction in skeletal fragility with leptin in our own studies is consistent with the in vitro effects of this hormone and is the more impressive since it occurs in the face of reduced body weight caused by leptin's central effect on appetite (Halaas et al. 1995). It is surprising that significant changes are not seen in the histomorphometric indices. This may reflect the relative insensitivity of histological measures, but it could also suggest that the effect on fragility is mediated by changes in bone architecture. In particular, strength in three-point bending is related to the fourth power of the external diameter of a bone, so the small increases in cortical thickness and mid-tibial width in the leptin-treated animals are sufficient to account for the observed changes in the bones' mechanical properties.

The positive effects of leptin on bone size, growth plate thickness and chondrocyte proliferation in the present studies suggest that it regulates bone growth. This is consistent with the reduced bone size of leptin-deficient mice (Steppan et al. 2000) and leptin-resistant rats (Mathey et al. 2002), and with evidence of a relationship between bone size and circulating leptin concentrations in adolescent women (Matkovic et al. 1997). It is also consistent with the recent report of Maor et al. (2002) that leptin directly promotes chondrocyte growth. Two studies of systemic leptin administration in ob/ob mice show dramatic positive effects on indices of bone formation (Liu et al. 1997), bone size and bone density (Steppan et al. 2000). These studies showed larger effects than the present study, probably because they were carried out in leptindeficient mice, although the younger age of the animals and the higher leptin doses used in those experiments may also have contributed. The positive effect of leptin on skeletal size suggests that this hormone may be a contributor to the increases in stature of successive generations of humans that have been observed over the last century or more (Reid 1996). As nutrition has improved, leptin concentrations may have increased with a consequent increase in growth.

While the studies reviewed above are in agreement with the present data, there is apparent disagreement between this body of evidence and the studies of Ducy et al. (2000). They reported that mice lacking either a functional leptin gene or the gene for its receptor had high bone densities. Both the leptin-deficient and wild-type mice showed a marked loss of bone when leptin was infused into their cerebral ventricles over a 28 -day period. The key difference between these studies and those reported in the present paper is the route of delivery of the leptin. Ducy et al. (2000) exclusively studied the influence of central leptin administration and have produced the fascinating conclusion that there is central regulation of bone mass. This appears to be mediated by a neurological rather than an endocrine mechanism, based on preliminary reports of cross-perfusion studies (Takeda et al. 2000). Taken together, these findings indicate that the direct effects of leptin on bone outweigh its indirect effects mediated by the central nervous system. Since leptin originates in the periphery, including production in bone marrow adipocytes (Laharrague et al. 1998) and directly from mature skeletal cells themselves (Reseland et al. 2001, Kume et al. 2002), bone will be exposed to much higher concentrations of leptin than is the central nervous system. This differential is even more marked in obesity, which is associated with reduced transfer of leptin across the blood-brain barrier (Caro et al. 1996). Thus, in vivo, its direct effects on bone (anabolic and anti-resorptive) will be even more dominant than they are in the present experimental model.

The present findings of modest positive effects of leptin on bone do not mean that this is the entire explanation for the dependence of bone density on fat mass. One other mechanism involved is insulin and other factors co-secreted with it from the pancreatic beta cell (e.g. 
amylin). High body weight is consistently associated with hyperinsulinaemia (Haffner \& Bauer 1993, Reid et al. 1993) and insulin acts directly on osteoblasts in vivo and in vitro to increase cell replication and matrix synthesis (Yano et al. 1994, Cornish et al. 1996). In vivo, this activity is augmented by amylin, which both stimulates osteoblast growth and inhibits osteoclastic bone resorption (Cornish \& Reid 1999). Insulin also acts on bone indirectly. It stimulates sex hormone production in women (Garzo \& Dorrington 1984) and men (Pasquali et al. 1995), and it inhibits hepatic synthesis of sex hormone-binding globulin, thereby reducing protein binding of sex hormones and increasing their free concentrations (Crave et al. 1995, Ykijarvinen et al. 1995, Katsuki et al. 1996). Thus, hyperinsulinaemic states in humans are consistently associated with increased bone density (Haffner \& Bauer 1993, Reid et al. 1993, Barrett-Connor \& Kritzsilverstein 1996, Stolk et al. 1996, Wetvik 1996, Abrahamsen et al. 2000) and hypoinsulinaemia is associated with osteoporosis (Utsugi et al. 2000).

There may be a role for insulin in explaining the central effect of leptin on bone mass, since central administration of leptin dramatically decreases circulating insulin concentrations (Kamohara et al. 1997, Scrocchi et al. 1997, Shi et al. 1998, Tannenbaum et al. 1998), via changes in insulin sensitivity mediated by the autonomic nervous system (Mizuno et al. 1998). Conversely in the ob/ob mouse, insulin concentrations are 10-fold higher than in wild-type controls (Herberg \& Kley 1975), which could contribute to its high bone mass. Systemic administration of leptin is associated with reduced insulin concentrations (Kulkarni et al. 1997, Scrocchi et al. 1997, Seufert et al. 1999, Shimomura et al. 1999), so the positive skeletal effects found in the present in vivo study in the face of these changes emphasise the direct effects of leptin on bone.

In conclusion, we have demonstrated that leptin acts directly on bone, influencing both osteoblasts and osteoclasts. As a result, systemic administration of leptin results in reduced bone fragility, in marked contrast to the results of its administration into the third ventricle of the brain. Since leptin is a systemic hormone, the present results imply that the peripheral effects of leptin on the skeleton outweigh its central action.

\section{Acknowledgements}

This work was funded by the Health Research Council of New Zealand and the Auckland Medical Research Foundation.

\section{References}

Abrahamsen B, Rohold A, Henriksen JE \& Beck-Nielsen H 2000 Correlations between insulin sensitivity and bone mineral density in non-diabetic men. Diabetic Medicine 17 124-129.
Barrett-Connor E \& Kritzsilverstein D 1996 Does hyperinsulinemia preserve bone. Diabetes Care 19 1388-1392.

Bassilana F, Susa M, Keller HJ \& Halleux C 2000 Human mesenchymal stem cells undergoing osteogenic differentiation express leptin and functional leptin receptor. Journal of Bone and Mineral Research 15 (Suppl 1) S378.

van Beresteijn EC, van Laarhoven JPRM \& Smals AGH 1992 Body weight and/or endogenous estradiol as determinants of cortical bone mass and bone loss in healthy early postmenopausal women. Acta Endocrinologica 127 226-230.

Blain H, Vuillemin A, Guillemin F, Durant R, Hanesse B, De Talance N, Doucet B \& Jeandel C 2002 Serum leptin level is a predictor of bone mineral density in postmenopausal women. Journal of Clinical Endocrinology and Metabolism 87 1030-1035.

Burguera B, Hofbauer LC, Thomas T, Gori F, Evans GL, Khosla S, Riggs BL \& Turner RT 2001 Leptin reduces ovariectomy-induced bone loss in rats. Endocrinology 142 3546-3553.

Caro JF, Kolaczynski JW, Nyce MR, Ohannesian JP, Opentanova I, Goldman WH, Lynn RB, Zhang PL, Sinha MK \& Considine RV 1996 Decreased cerebrospinal-fluid/serum leptin ratio in obesity: a possible mechanism for leptin resistance. Lancet 348 159-161.

Chomczynski P \& Sacchi N 1987 Single-step method of RNA isolation by acid guanidinium thiocyanate-phenol-chloroform. Analytical Biochemistry 162 156-159.

Compston JE, Bhambhani M, Laskey MA, Murphy S \& Khaw KT 1992 Body composition and bone mass in post-menopausal women. Clinical Endocrinology 37 426-431.

Cornish J \& Reid IR 1999 Skeletal effects of amylin and related peptides. Endocrinologist 9 183-189.

Cornish J, Callon KE \& Reid IR 1996 Insulin increases histomorphometric indices of bone formation in vivo. Calcified Tissue International 59 492-495.

Cornish J, Callon KE, King AR, Cooper GJS \& Reid IR 1998 Systemic administration of amylin increases bone mass, linear growth, and adiposity in adult male mice. American Journal of Physiology. Endocrinology and Metabolism 275 E694-E699.

Cornish J, Callon KE, Lin CQX, Xiao CL, Mulvey TB, Cooper GJS \& Reid IR 1999 Trifluoroacetate, a contaminant in purified proteins, inhibits proliferation of osteoblasts and chondrocytes. American Journal of Physiology. Endocrinology and Metabolism 277 E779-E783.

Cornish J, Callon KE, Gasser JA, Bava U, Gardiner EM, Coy DH, Cooper GJS \& Reid IR 2000 Systemic administration of a novel octapeptide, amylin-(1-8), increases bone volume in male mice. American Journal of Physiology. Endocrinology and Metabolism 279 E730-E735.

Cornish J, Callon KE, Bava U, Coy DH, Mulvey TB, Murray MAF, Cooper GJS \& Reid IR 2001 Systemic administration of adrenomedullin(27-52) increases bone volume and strength in male mice. Journal of Endocrinology 170 251-257.

Crave JC, Lejeune H, Brebant C, Baret C \& Pugeat M 1995 Differential effects of insulin and insulin-like growth factor I on the production of plasma steroid-binding globulins by human hepatoblastoma-derived (Hep G2) cells. Journal of Clinical Endocrinology and Metabolism 80 1283-1289.

Ducy P, Amling M, Takeda S, Priemel M, Schilling AF, Beil FT, Shen JH, Vinson C, Rueger JM \& Karsenty G 2000 Leptin inhibits bone formation through a hypothalamic relay: a central control of bone mass. Cell 100 197-207.

Enjuanes A, Supervia A, Nogues X \& Diez-Perez A 2002 Leptin receptor $(\mathrm{OB}-\mathrm{R})$ gene expression in human primary osteoblasts: confirmation. Journal of Bone and Mineral Research 171135.

Felson DT, Zhang YQ, Hannan MT \& Anderson JJ 1993 Effects of weight and body mass index on bone mineral density in men and women - the Framingham study. Journal of Bone and Mineral Research 8 567-573. 
Gardsell P, Johnell O \& Nilsson BE 1989 Predicting fractures in women by using forearm bone densitometry. Calcified Tissue International 44 235-242.

Garzo VG \& Dorrington JH 1984 Aromatase activity in human granulosa cells during follicular development and the modulation of follicle-stimulating hormone and insulin. American Journal of Obstetrics and Gynecology 148 657-662.

Gordeladze JO, Drevon CA, Syversen U \& Reseland JE 2002 Leptin stimulates human osteoblastic cell proliferation, de novo collagen synthesis, and mineralization: impact on differentiation markers, apoptosis, and osteoclastic signaling. Journal of Cellular Biochemistry $85825-836$

Goulding A \& Taylor RW 1998 Plasma leptin values in relation to bone mass and density and to dynamic biochemical markers of bone resorption and formation in postmenopausal women. Calcified Tissue International 63 456-458.

Greenspan SL, Myers ER, Maitland LA, Resnick NM \& Hayes WC 1994 Fall severity and bone mineral density as risk factors for hip fracture in ambulatory elderly. Journal of the American Medical Association 271 128-133.

Grey A, Banovic T, Naot D, Hill B, Callon K, Reid I \& Cornish J 2001 Lysophosphatidic acid is an osteoblast mitogen whose proliferative actions involve $\mathrm{G}(\mathrm{i})$ proteins and protein kinase $\mathrm{C}$, but not p42/44 mitogen-activated protein kinases. Endocrinology 142 1098-1106.

Groot CG, Danes JK, van der Meer JM \& Herrmann-Erlee MPM 1985 Osteocalcin antigenicity in cultured osteoblast-like cells after stimulation with 1,25-vitamin D3. Cell Biology International Reports 9528.

Haffner SM \& Bauer RL 1993 The association of obesity and glucose and insulin concentrations with bone density in premenopausal and postmenopausal women. Metabolism: Clinical and Experimental 42 735-738.

Halaas JL, Gajiwala KS, Maffei M, Cohen SL, Chait BT, Rabinowitz D, Lallone RL, Burley SK \& Friedman JM 1995 Weight-reducing effects of the plasma protein encoded by the obese gene. Science $\mathbf{2 6 9}$ 543-546.

Hassager C \& Christiansen C 1989 Influence of soft tissue body composition on bone mass and metabolism. Bone 10 415-419.

Herberg L \& Kley HK 1975 Adrenal function and the effect of a high fat diet on C57BL/6J and C57BL/6J-ob/ob mice. Hormone and Metabolic Research 7 410-415.

Herrmann-Erlee MPM \& van der Meer JM 1986 The effect of PTH and PGE2 on growth and differentiation of primary fetal rat osteblast-like cells, on UMR 106 osteosarcoma cells, and on a SV40 transformed 'osteoblast-like' cell line. Program of the IX International Conference on Calcium Regulatory Hormones and Bone Metabolism, Montreal, Canada. p 409 (Abstract).

Holloway WR, Collier FM, Aitken CJ, Myers DE, Hodge JM, Malakellis M, Gough TJ, Collier GR \& Nicholson GC 2002 Leptin inhibits osteoclast generation. Journal of Bone and Mineral Research 17 200-209.

Iwaniec UT, Shearon CC, Heaney RP, Cullen DM \& Yee JA 1998 Leptin increases number of bone nodules in vitro. Bone $\mathbf{2 3}$ (Suppl 5) S212.

Kamohara S, Burcelin R, Halaas JL, Friedman JM \& Charron MJ 1997 Acute stimulation of glucose metabolism in mice by leptin treatment. Nature 389 374-377.

Katsuki A, Sumida Y, Murashima S, Fujii M, Ito K, Tsuchihashi K, Murata K, Yano Y \& Shima T 1996 Acute and chronic regulation of serum sex hormone-binding globulin levels by plasma insulin concentrations in male noninsulin-dependent diabetes mellitus patients. Journal of Clinical Endocrinology and Metabolism $\mathbf{8 1}$ 2515-2519.

Khosla S, Atkinson EJ, Riggs BL \& Melton LJ 1996 Relationship between body composition and bone mass in women. Journal of Bone and Mineral Research 11 857-863.
Kulkarni RN, Wang ZL, Wang RM, Hurley JD, Smith DM, Ghatei MA, Withers DJ, Gardiner JV, Bailey CJ \& Bloom SR 1997 Leptin rapidly suppresses insulin release from insulinoma cells, rat and human islets and, in vivo, in mice. Journal of Clinical Investigation 100 2729-2736.

Kume K, Satomura K, Nishisho S, Kitaoka E, Yamanouchi K, Tobiume S \& Nagayama M 2002 Potential role of leptin in endochondral ossification. Journal of Histochemistry and Cytochemistry 50 159-169.

Laharrague P, Larrouy D, Fontanilles AM, Truel N, Campfield A, Tenenbaum R, Galitzky J, Corberand JX, Penicaud L \& Casteilla L 1998 High expression of leptin by human bone marrow adipocytes in primary culture. FASEB Journal 12 747-752.

Lee YJ, Park JH, Ko JS \& Kim HM 2001 Expression of signaltransducing leptin receptors on rat osteoblasts indicates a direct involvement of leptin in the regulation of bone formation. Journal of Bone and Mineral Research 16 (Suppl 1) S495.

Liu C, Grossmann A, Bain S, Strachan M, Puemer D, Bailey C, Humes J, Lenox J, Yamamoto G, Sprugel K, Kuijper J, Weigle S, Dumam D \& Moore E 1997 Leptin stimulates cortical bone formation in obese $(\mathrm{ob} / \mathrm{ob})$ mice. Journal of Bone and Mineral Research 12 (Suppl 1) S115.

Lowe C, Cornish J, Martin TJ \& Reid IR 1991 Effects of leukemia inhibitory factor on bone resorption and DNA synthesis in neonatal mouse calvaria. Calcified Tissue International 49 394-397.

Maor G, Rochwerger M, Segev Y \& Phillip M 2002 Leptin acts as a growth factor on the chondrocytes of skeletal growth centers. Journal of Bone and Mineral Research 17 1034-1043.

Mathey J, Horcajada-Molteni MN, Chanteranne B, Picherit C, Puel C, Lebecque P, Cubizoles C, Davicco MJ, Coxam V \& Barlet JP 2002 Bone mass in obese diabetic Zucker rats: influence of treadmill running. Calcified Tissue International 70 305-311.

Matkovic V, Ilich JZ, Skugor M, Badenhop NE, Goel P, Clairmont A, Klisovic D, Nahhas RW \& Landoll JD 1997 Leptin is inversely related to age at menarche in human females. Journal of Clinical Endocrinology and Metabolism 82 3239-3245.

Mazess R, Barden H, Ettinger B, Johnston C, Dawson-Hughes B, Baran D, Powell M \& Notelovitz M 1987 Spine and femur density using dual-photon absorptiometry in US white women. Bone and Mineral 2 211-219.

Mizuno A, Murakami T, Otani S, Kuwajima M \& Shima K 1998 Leptin affects pancreatic endocrine functions through the sympathetic nervous system. Endocrinology 139 3863-3870.

Muscaritoli M, Gleason JR, Meguid MM \& Lukaski HC 1993 Densitometry-based equations for estimating body composition in Fischer rats. Nutrition 9 439-445.

Ogueh O, Sooranna S, Nicolaides KH \& Johnson MR 2000 The relationship between leptin concentration and bone metabolism in the human fetus. Journal of Clinical Endocrinology and Metabolism 85 1997-1999.

Parfitt AM, Mathews CHE, Villanueva AR, Kleerekoper M, Frame B \& Rao DS 1983 Relationships between surface, volume, and thickness of iliac trabecular bone in aging and osteoporosis. Journal of Clinical Investigation 72 1396-1409.

Pasco JA, Henry MJ, Kotowicz MA, Collier GR, Ball MJ, Ugoni AM \& Nicholson GC 2001 Serum leptin levels are associated with bone mass in nonobese women. Journal of Clinical Endocrinology and Metabolism 86 1884-1887.

Pasquali R, Casimirri F, Deiasio R, Mesini P, Boschi S, Chierici R, Flamia R, Biscotti M \& Vicennati V 1995 Insulin regulates testosterone and sex hormone-binding globulin concentrations in adult normal weight and obese men. Journal of Clinical Endocrinology and Metabolism 80 654-658.

Pighetti GM, Hitt DC \& Gimble JM 1999 Leptin: its role in hematopoiesis and bone formation. Journal of Clinical Ligand Assay 22 239-241.

Reid IR 1996 Has improved nutrition contributed to the hip fracture epidemic. Molecular and Cellular Endocrinology 123 123-125. 
Reid IR, Lowe C, Cornish J, Skinner SJM, Hilton DJ, Willson TA, Gearing DP \& Martin TJ 1990 Leukemia inhibitory factor: a novel bone-active cytokine. Endocrinology 126 1416-1420.

Reid IR, Ames R, Evans MC, Sharpe S, Gamble G, France JT, Lim TMT \& Cundy TF $1992 a$ Determinants of total body and regional bone mineral density in normal postmenopausal women - a key role for fat mass. Journal of Clinical Endocrinology and Metabolism $\mathbf{7 5}$ $45-51$.

Reid IR, Plank LD \& Evans MC $1992 b$ Fat mass is an important determinant of whole body bone density in premenopausal women but not in men. Journal of Clinical Endocrinology and Metabolism $\mathbf{7 5}$ 779-782.

Reid IR, Evans MC, Cooper GJS, Ames RW \& Stapleton J 1993 Circulating insulin levels are related to bone density in normal postmenopausal women. American Journal of Physiology 265 E655-E659.

Reid IR, Ames RW, Evans MC, Sharpe SJ \& Gamble GD 1994a Determinants of the rate of bone loss in normal postmenopausal women. Journal of Clinical Endocrinology and Metabolism 79 950-954.

Reid IR, Evans MC \& Ames RW $1994 b$ Volumetric bone density of the lumbar spine is related to fat mass but not lean mass in normal postmenopausal women. Osteoporosis International 4 362-367.

Reseland JE, Syversen U, Bakke I, Qvigstad G, Eide LG, Hjertner O, Gordeladze JO \& Drevon CA 2001 Leptin is expressed in and secreted from primary cultures of human osteoblasts and promotes bone mineralization. Journal of Bone and Mineral Research 16 1426-1433.

Schott AM, Cormier C, Hans D, Favier F, Hausherr E, Dargent-Molina P, Delmas PD, Ribot C, Sebert JL, Breart G \& Meunier PJ 1998 How hip and whole-body bone mineral density predict hip fracture in elderly women: the EPIDOS prospective study. Osteoporosis International 8 247-254.

Scrocchi LA, Brown TJ \& Drucker DJ 1997 Leptin sensitivity in nonobese glucagon-like peptide I receptor - / - mice. Diabetes 46 2029-2034.

Seufert J, Kieffer TJ \& Habener JF 1999 Leptin inhibits insulin gene transcription and reverses hyperinsulinemia in leptin-deficient ob/ob mice. PNAS 96 674-679.

Shi ZQ, Nelson A, Whitcomb L, Wang J \& Cohen AM 1998 Intracerebroventricular administration of leptin markedly enhances insulin sensitivity and systemic glucose utilization in conscious rats. Metabolism: Clinical and Experimental 47 1274-1280.

Shimomura I, Hammer RE, Ikemoto S, Brown MS \& Goldstein JL 1999 Leptin reverses insulin resistance and diabetes mellitus in mice with congenital lipodystrophy. Nature 401 73-76.

Steppan CM, Crawford DT, Chidsey-Frink KL, Ke HZ \& Swick AG 2000 Leptin is a potent stimulator of bone growth in ob/ob mice. Regulatory Peptides 92 73-78.
Stolk RP, Vandaele PLA, Pols HAP, Burger H, Hofman A, Birkenhager JC, Lamberts SWJ \& Grobbee DE 1996 Hyperinsulinemia and bone mineral density in an elderly population - the Rotterdam study. Bone 18 545-549.

Sufang C, Nemoto K, Kurose R, Kobayashi N, Kubo K \& Itabashi A 2000 Different expression of leptin receptor variants in MC3T3-E1 osteoblastic cells and ATDC-5 chondroblastic cells. Journal of Bone and Mineral Research 15 (Suppl 1) S466.

Takeda S, Elefteriou F, Priemel M, Rueger JM, Amling M, Ducy P \& Karsenty G 2000 Leptin controls bone formation exclusively through a central pathway and at a dose that has no effect on body weight. Journal of Bone and Mineral Research 15 (Suppl 1) S180.

Tannenbaum GS, Gurd W \& Lapointe M 1998 Leptin is a potent stimulator of spontaneous pulsatile growth hormone $(\mathrm{GH})$ secretion and the GH response to GH-releasing hormone. Endocrinology 139 $3871-3875$.

Thomas T, Gori F, Khosla S, Jensen MD, Burguera B \& Riggs BL 1999 Leptin acts on human marrow stromal cells to enhance differentiation to osteoblasts and to inhibit differentiation to adipocytes. Endocrinology 140 1630-1638.

Utsugi T, Ohno T, Ohyama Y, Uchiyama T, Saito Y, Matsumura Y, Aizawa $\mathrm{H}$, Itoh $\mathrm{H}$, Kurabayashi M, Kawazu S, Tomono S, Oka Y, Suga T, Kuro-o M, Nabeshima Y \& Nagai R 2000 Decreased insulin production and increased insulin sensitivity in the Klotho mutant mouse, a novel animal model for human aging. Metabolism: Clinical and Experimental 49 1118-1123.

Wetvik J 1996 Radiological features in generalized lipodystrophy. Acta Paediatrica 413 (Suppl) 44-51.

Yamauchi M, Sugimoto T, Yamaguchi T, Nakaoka D, Kanzawa M, Yano S, Ozuru R, Sugishita T \& Chihara K 2001 Plasma leptin concentrations are associated with bone mineral density and the presence of vertebral fractures in postmenopausal women. Clinical Endocrinology 55 341-347.

Yano H, Ohya K \& Amagasa T 1994 Effects of insulin on in vitro bone formation in fetal rat parietal bone. Endocrine Journal 41 293-300.

Ykijarvinen H, Makimattila S, Utriainen T \& Rutanen EM 1995 Portal insulin concentrations rather than insulin sensitivity regulate serum sex hormone-binding globulin and insulin-like growth factor binding protein 1 in vivo. Journal of Clinical Endocrinology and Metabolism 80 3227-3232.

Received 11 July 2002

Accepted 18 July 2002 